\title{
Social Media Analysis during Covid-19: A Systematic Review
}

\section{Binita Verma}

\begin{abstract}
In 2020 and 2021, during thisepidemic period, communication has never been so easy in human history. Social media plays an important role in disseminating information. Yet, there are many pros and cons challenges, and false information to consider. The use of these resources can help to quickly disseminate valuable information, findings in specific new research, exchange guidelines for analysis, treatment, and compliance, and also comparisons of various methods around the world. It is recommended that we follow certain guidelines when sharing information on social networks during COVID19, to use these resources effectively and efficiently. This study highlighted the review o-19 and encouraged further efforts to clarify this field of research.
\end{abstract}

Keyword: Covid-19, social media, Pandemic, Coronavirus

\section{INTRODUCTION}

COVID-19 is a new virus that has suddenly spread all over the world (1). It is originated from Wuhan city of China. There are so many people are infected around the world [2]. It is a critical issue for public health, as well as individuals and the community. People expect to know what actions can be taken to prevent and treat this virus, just as they do with other epidemic diseases. Persons are using social media networking sites to know about COVID19 during the lockdown. The impact of digital panic on users usually depends on the gender, age, and level of education of the person [3]. The usage of social media has played a significant role in spreading awareness about the COVID-19 outbreak around the world [4]. During covid19, digital media also used to communicate health information to the people [5]. Some diseases like covid19 use media for information. Covid19 pandemic spread in many countries and halt all the work. Academic institutions and businesses were closed down. People have done their work from home. All cities and villages were quarantined to reduce the spread of Covid19. People are panicked due to the mass knowledge and disinformation on COVID-19 on social media and other online outlets, and the healthcare systems in various countries are collapsing under the encumbrance. So, social media hasplayed a key role in people's understanding of disease exposure [6][7], resultant decision-making, and risk behaviors. As a result, reliable and timely information about threats must be distributed to the general public.

Manuscript received on June 30, 2021

Revised Manuscript received on July 05, 2021.

Manuscript published on July 30, 2021.

* Correspondence Author

Dr. Binita Verma*, Assistant Professor, Department of science and Technology, Jayoti Vidyapeeth Womens University, Jaipur, India.

(C) The Authors. Published by Blue Eyes Intelligence Engineering and Sciences Publication (BEIESP). This is an open access article under the CC BY-NC-ND license (http://creativecommons.org/licenses/by-nc$\underline{\mathrm{nd} / 4.0 /)}$
Research techniques used in research published on social media and emerging infectious diseases were analyses in systematic analysis.

\section{RELATED WORK}

The Covid19 pandemic has encouraged various researchers, scientists, laboratories and organizations all over the world to research the impact of social media.

In recent months, quite a lot of papers were published examining various aspects of COVID-19 [8]-[14]. To determine the social media analysis during COVID-19, Laszlo Nemes and Attila Kiss [15] concluded that the sentiments and expressions of the users of social networking site Twitter were based on the main trend keywords covid-19 andpandemics, with NLP and emotional classification using the RNN. They have developed a model for analyzing the emotional state of various tweets, using a RNN for emotive prediction, searching forconnection between words, and placing them in positive or negative sentiments. Social media networking sites play an important role in providing information related to Coronavirus. false information, fake news and rumors spread in the media that panicked people to take decisions [16]. During the COVID-19 epidemic, fake news became a main problem on social media. Ahmed et al. [17] said that Facebook has introduced a new feature that will alert users when they come in contact with incorrect information. According to some information, accounts like Twitter and health care accounts have a very small amount of unverified information. Mis-information on social media such as Facebook about possible drugs, including the Coronavirus treatment hydroxychloroquine, has led many people to purchase such drugs without a medical advisor, due to a shortage of these drugs for patients who need them [18].

\section{OBJECTIVES}

The aim of this research paper is to make the review of social media analysis during Covid-19andprofoundlearning.

Some of the main approaches listed in our study are: -

- $\quad$ Pros and cons of social media during Covid-19 pandemic

- $\quad$ Façade or misinformation

- Challenges of using social media.

\section{DISCUSSION}

Pros and cons of social media during Covid-19 pandemic

In the COVID-19 pandemic period, social media has noteworthy advantages in terms of the fast distribution of informative knowledge.
Blue Eyes Intelligence Engineering and Sciences Publication (C) Copyright: All rights reserved.

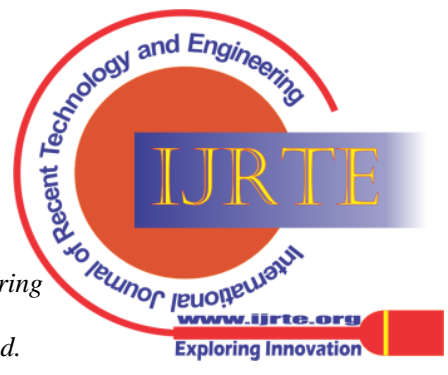


Faster distribution of preventive measures information has a lot of potentials. According to a recent survey, the maximum watched videos on YouTube with the term "coronavirus" or "covid19" had over and above 150 million views as of March 2020, with most videos of them belonging to news channels. About one-third of the videos discussed preventive measures, and about half mentioned the most common symptoms. yet, almost all of the videos talked about death, nervousness, and the state of quarantine. This study prompts us to consider the potential for the distribution of high-quality knowledge on the prevention of infection and common symptoms of infection that have been neglected. During the COVID-19 epidemic, social media networking sites provided the opportunity to organize collaborative research projects, research, and multidisciplinary studies. social media sites such as Zoom and YouTube will assist in further medical education with the hosting of live and recorded webinars.

The dark side of social media networking sites has been highlighted in the tsunami of incorrect and dishonest news that ranged from selling fake cures to using the social media as a platform to launch cyberattackson critical information systems.

\section{Facade or misinformation}

From April 2020, a large number of research publications are published.On the other side of the coin, False information spreads at the same pace as information, which is why some authors have suggested that they form groups that will work to combat myths and misinformation on social media [19]. In this way, the World Health Organization has created a special section on its website dedicated to the myths of debunking coronavirus.

\section{Challenges of using social media}

Previous research has shown that social media has helped present the public with factual data. They follow and respond to myths and rumors, disputing with evidencebased information and disseminating accurate information on their forums [20]. Research of social media rumors during critical events highlights the importance of releasing powerful updates from time to time from reliable sources.

Finally, the influence of social media to spread erroneous, frightening and exaggerated information that can create depression, fear, anxiety and also stressin people unless mental illness may be their worst face.

\section{CONCLUSION}

In this research paper, we concluded that the current review's findings suggest that social media platforms have a high potential for health care awareness, spread knowledge and education during the covid-19 pandemic. It is also good for preserving social distance and stay at home. Social media having various cons also. Experts can use this review to prevent the outbreak of covid19 disease.

Table I. Summary of some selected articles related to Covid-19 pandemic Social medial analysis.

\begin{tabular}{|c|c|c|c|c|c|}
\hline S.No & Author & Description & Technique used & Dataset & $\begin{array}{c}\text { Duration of } \\
\text { collection dataset }\end{array}$ \\
\hline 1 & $\begin{array}{l}\text { Mohammed } \\
\text { Emitiaz et al. } \\
2020 \text { [21] }\end{array}$ & $\begin{array}{l}\text { To analyze public } \\
\text { sentiment on reopening. } \\
\text { People have a less } \\
\text { negative } \\
\text { towards the situation of re- } \\
\text { opening. }\end{array}$ & $\begin{array}{l}\mathrm{N} \text {-gram } \\
\text { representation }\end{array}$ & $\begin{array}{l}\text { Twitter, Time-series } \\
\text { dataset from GitHub } \\
\text { repository } \\
\text { Python }\end{array}$ & $\begin{array}{l}3 \text { may } 2020 \text { to } 15 \\
\text { may } 2020\end{array}$ \\
\hline 2 & $\begin{array}{l}\text { Laszlo } \\
\text { Nemeset al. } \\
{[15]}\end{array}$ & $\begin{array}{l}\text { They developed a model to } \\
\text { evaluates the emotional } \\
\text { states of various tweets for } \\
\text { emotional prediction, } \\
\text { marking with +ve and -ve } \\
\text { emotions. }\end{array}$ & $\begin{array}{lr}\text { Recurrent } & \text { Neural } \\
\text { Network- } & \text { Deep } \\
\text { Learning } & \end{array}$ & Twitter & $\begin{array}{l}\text { 13-14 May (200 } \\
\text { tweets), } 24-25 \\
\text { April (500 tweets) }\end{array}$ \\
\hline 3 & $\begin{array}{l}\text { Kamaran H. } \\
\text { Manguri et al. } \\
{[22]}\end{array}$ & $\begin{array}{l}\text { The aim of this analysis is } \\
\text { to identify the emotional } \\
\text { state of people about } \\
\text { coronavirus. } \\
\text { determining polarity and } \\
\text { subjectivity }\end{array}$ & $\begin{array}{lr}\text { Naive } & \text { Bayes } \\
\text { model, } & \text { Deep } \\
\text { learning- RNN }\end{array}$ & Twitter & $\begin{array}{l}9 \text { to15 April, } \\
2020\end{array}$ \\
\hline 4 & $\begin{array}{l}\text { Man hung et } \\
\text { al. [23] }\end{array}$ & $\begin{array}{l}\text { The study was to evaluate } \\
\text { a discussion about covid- } \\
19 \text { on Twitterdata and their } \\
\text { sentiments. }\end{array}$ & $\begin{array}{l}\text { Machine learning } \\
\text { approaches in the } \\
\text { field of AI }\end{array}$ & Twitter & $\begin{array}{l}20 \text { March to } 19 \\
\text { April, } 2020\end{array}$ \\
\hline
\end{tabular}

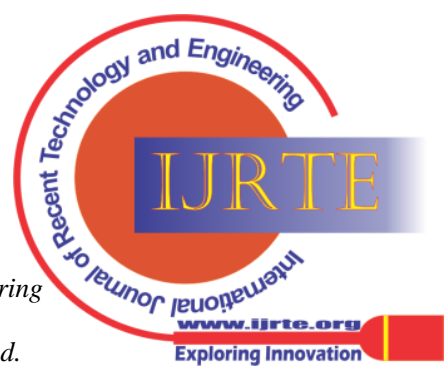




\begin{tabular}{|c|c|c|c|c|c|}
\hline 5 & $\begin{array}{l}\text { Jianlong Zhou } \\
\text { et al. [24] }\end{array}$ & $\begin{array}{l}\text { During pandemic, } \\
\text { Analyzing the feelings of } \\
\text { dynamics of people who } \\
\text { live in Australia }\end{array}$ & $\begin{array}{l}\text { VADER to analyze } \\
\text { sentiments implied } \\
\text { in tweets }\end{array}$ & Twitter & $\begin{array}{l}1 \text { Jan to } 22 \text { May, } \\
2020\end{array}$ \\
\hline 6 & $\begin{array}{l}\text { A Mourad. et } \\
\text { al. [25] }\end{array}$ & $\begin{array}{l}\text { The negative influence of } \\
\text { covid19 overcoming the } \\
\text { epidemic with huge } \\
\text { Twitter data that has } \\
\text { provided quantitative } \\
\text { assessment using real life } \\
\text { experiments that reflect } \\
\text { the environment itself. }\end{array}$ & $\begin{array}{lr}\text { Lexicon } & \text { Based } \\
\text { data analytics } \\
\text { Methodology }\end{array}$ & Tweets & - \\
\hline 7 & $\begin{array}{l}\text { T. Da and L. } \\
\text { Z. Xi,[26] }\end{array}$ & $\begin{array}{l}\text { They study that how } \\
\text { covid-19 pandemic effects } \\
\text { sentiments and also the } \\
\text { implementation is easy. } \\
\text { They make known } \\
\text { thathow covid19 like } \\
\text { pandemics affects the } \\
\text { people's sentiments,to } \\
\text { categorize the sentiments } \\
\text { and resolve the related } \\
\text { socio-economic problems. }\end{array}$ & $\begin{array}{l}\text { A multipurpose } \\
\text { model which is } \\
\text { state of art NLP } \\
\text { pretrained } \\
\text { sentiments. }\end{array}$ & $\begin{array}{l}\text { Tweets taken from } \\
\text { Sinaweibo10,815,385 }\end{array}$ & Feb-20 \\
\hline 8 & $\begin{array}{l}\text { V. } \\
\text { Chakkarwar } \\
\text { and S. } \\
\text { Tamane, [27] }\end{array}$ & $\begin{array}{l}\text { Data retrieval model using } \\
\text { a topic model that analyzes } \\
\text { the impact of the covid-19 } \\
\text { epidemic in India }\end{array}$ & $\begin{array}{l}\text { Topic modeling } \\
\text { applied to twitter } \\
\text { dataset and } \\
\text { generated a very } \\
\text { useful topic which } \\
\text { gives an idea of } \\
\text { public views } \\
\text { during the } \\
\text { pandemic. They } \\
\text { used BOW and a } \\
\text { TF-IDF model to } \\
\text { extract topics from } \\
\text { the dataset of } \\
\text { twitter. }\end{array}$ & 3500 tweets & $\begin{array}{l}\text { March and April, } \\
2020\end{array}$ \\
\hline 9 & $\begin{array}{l}\text { T. Wang et al. } \\
\text { [28] }\end{array}$ & $\begin{array}{l}\text { Their analysis provides } \\
\text { insight into the evolution } \\
\text { of social sentimentsfrom } \\
\text { time to time and the } \\
\text { weibos post the topics } \\
\text { related to negative } \\
\text { sentiments. }\end{array}$ & 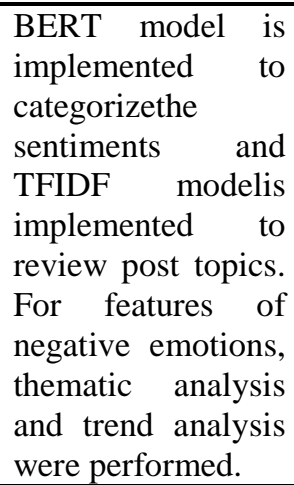 & $\begin{array}{ll}999,978 & \text { sinaweibo } \\
\text { post } & \end{array}$ & $\begin{array}{l}1 \text { Jan to } 18 \text { Feb, } \\
2020\end{array}$ \\
\hline 10 & $\begin{array}{l}\text { R. Wang et al. } \\
\text { [29] }\end{array}$ & $\begin{array}{l}\text { From social networking } \\
\text { sites data, they developa } \\
\text { model to get sentiment } \\
\text { analysis during the } \\
\text { pandemic and also a } \\
\text { technique fake news } \\
\text { detection which is based } \\
\text { on different machine } \\
\text { learning approaches. }\end{array}$ & $\begin{array}{l}\text { Theypredict the } \\
\text { increase of the } \\
\text { epidemic by using } \\
\text { the least squares } \\
\text { and particle swarm } \\
\text { optimization } \\
\text { methods associated } \\
\text { with the existing } \\
\text { SIR model. }\end{array}$ & 100,000 Weibo data & $\begin{array}{l}1 \text { Jan to } 20 \mathrm{Feb} \text {, } \\
2020\end{array}$ \\
\hline
\end{tabular}

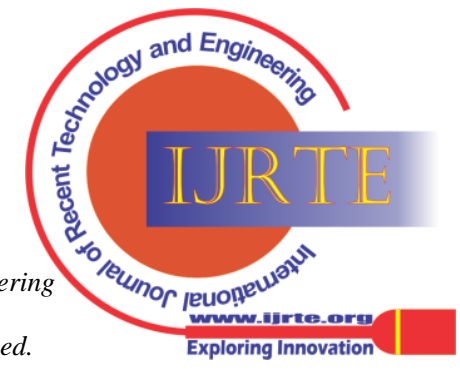




\section{REFERENCES}

1. T. Singhal, "A Review of Coronavirus Disease-2019 (COVID-19)," Indian J Pediatr., 87(4), pp. 281-286, 2020.

2. Coronavirus. Available [Last retrieved on 2020 Apr 24].

3. Binita Verma andRamjeevan Singh Thakur, "Sentiment Analysis Using Lexicon and Machine Learning-Based Approaches: A Survey", Proceedings of International Conference on Recent Advancement on Computer and Communication, Lecture Notes in Networks and Systems 34, pp. 441-447, 2018.

4. H. Shaniand H. Sharma,"Role of Social media during the COVID-19 Pandemic: Beneficial, Destructive, or reconstructive?,” Int J Acad Md, Vol. 6(2), pp-70-75, 2020.

5. Tsao SF, Chen H, Tisseverasinghe T, Yang Y, Li L, Butt ZA, "What social media told us in the time of COVID-19: a scoping review," Lancet Digit Health, Vol. 3(3), pp. 175-194, March 2021.

6. Binita Verma, Ramjeevan Singh Thakur and Shailesh Jaloree, "Predicting Sentiment from Movie Reviews Using Lexicon Based Model," International Journal of Computer Sciences and Engineering, Vol.6, Issue.10, pp.28-34, 2018.

7. Binita Verma, Ramjeevan Singh Thakur and Shailesh Jaloree, "Predicting Sentiment from Movie Reviews Using Machine Learning Approach", International Journal of Scientific Research in Computer Science Applications and Management Studies, Vol. 7, Issue 4, 2018.

8. L. Fang, G. Karakiulakis, and M. Roth, "Are patients with hypertension and diabetes mellitus at increased risk for COVID-19 infection?," Lancet. Respiratory Med., vol. 8(4), April 2020.

9. SH Wong, RN Lui and JJ Sung, "Covid-19 and the digestive system," J Gastroenterol Hepatol., Vol.35(5), pp. 744-748, 2020.

10. R. Baldwin and E. Tomiura, "Thinking ahead about the trade impact of COVID-19," Economics in the Time COVID-19, pp. 59, 2020.

11. V. Surveillances, "The epidemiological characteristics of an outbreak of 2019 novel coronavirus diseases (COVID-19) China, 2020," China CDC Weekly, Vol. 2, no. 8, pp. 113-122, 2020.

12. H. Chen, J. Guo, C. Wang, F. Luo, X. Yu, W. Zhang, J. Li, D. Zhao, D. $\mathrm{Xu}, \mathrm{Q}$. Gong, J. Liao, H. Yang, W. Hou, and Y. Zhang, "Clinical characteristics and intrauterine vertical transmission potential of COVID-19 infection in nine pregnant women: A retrospective review of medical records", Lancet, Vol. 395, no. 10226, pp. 809-815,2020.

13. D. Wang, B. Hu, C. Hu, F. Zhu, X. Liu, J. Zhang, B. Wang, H. Xiang, Z. Cheng, Y. Xiong, Y. Zhao, Y. Li, X. Wang, and Z. Peng, "Clinical characteristics of 138 hospitalized patients with 2019 novel coronavirus- infected pneumonia in Wuhan, China," J. Amer. Med. Assoc., vol. 323, no. 11, pp. 1061, 2020.

14. N. Chen, M. Zhou, X. Dong, J. Qu, F. Gong, Y. Han, Y. Qiu, J. Wang, Y. Liu, Y. Wei, J. Xia, T. Yu, X. Zhang, and L. Zhang, "Epidemiological and clinical characteristics of 99 cases of 2019 novel coronavirus pneumonia in Wuhan, China: A descriptive study,” Lancet, vol. 395, no. 10223, pp. 507-513, 2020

15. Laszlo Nemes\& Attila Kiss, "Social media sentiment analysis based on COVID-19," Journal of Information and Telecommunication, 5:1, pp. 1-15, 2021.

16. M. O'Brien, K. Moore and F. McNicholas, "Social Media Spread During Covid-19: The Pros and Cons of Likes and Shares," Irish Medical Journal, Issue: Ir Med J; Vol 113, No. 4,pp. 52

17. A. Depoux, S. Martin,E.Karafillakis, R. Preet, A. Wilder-Smith, H. Larson, "The pandemic of social media panic travels faster than theCovid19 outbreak",Journal of Travel Medicine, 27(3), pp. 27, 2020

18. Kouzy, R., Jaoude, J. A., Kraitem, A., Alam, M. B. E., Karam, B., Adib, E., Zarka, J., Traboulsi, C., Akl, E., Baddour, K.,"Coronavirus Goes Viral: Quantifying the COVID-19 Misinformation Epidemic on Twitter"Cureus, vol. 3, pp. 12, 2020.

19. Al-Zaman, M.S., "COVID-19-Related Social Media Fake News in India,"Journalism and Media, pp. 100-114, 2020.

20. Ahmed, W., Vidal-Alaball, J., Downing, J., Seguí, L., F, “Dangerous Messages or Satire? Analysing the Conspiracy Theory Linking $5 \mathrm{G}$ to COVID-19 through Social Network Analysis," Journal of Medical Internet Research, Vol.22, 2020.

21. Ahmed, Mohammed Emtiaz, Rabin, Md Rafiqul Islam, Chowdhury and Farah Naz, "COVID-19: Social Media Sentiment Analysis on Reopening”, Book,june 2020

22. Kamaran Hussein Manguri, RebazNajeeb Ramadhan andPshkoRasul Mohammed Amin, "Twitter Sentiment Analysis on Worldwide COVID-19 Outbreaks,” Kurdistan Journal of Applied Research, pp. 5465, may 2019

23. Lipsky,Marton\& Hung, Man,"Men and COVID-19: A Pathophysiologic Review,” American Journal of Men's Health, vol. 14, September2020.
24. Zhou, Jianlong\& Yang, Shuiqiao\&Xiao, Chun \& Chen, Fang.,"Examination of community sentiment dynamics due to covid-19 pandemic: a case study from Australia," June2020

25. A. Mourad, A. Srour, H. Harmanai, C. Jenainati and M. Arafeh, "Critical Impact of Social Networks Infodemic on Defeating Coronavirus COVID-19 Pandemic: Twitter-Based Study and Research Directions," in IEEE Transactions on Network and Service Management, vol. 17, no. 4, pp. 2145-2155, Dec. 2020.

26. Ting Da And Liang Yang, Local COVID-19 Severity and Social Media Responses: Evidence from China," Vol 8,pp. 204684-94, November 2020.

27. V. Chakkarwar and S. Tamane, "Social Media Analytics during Pandemic for Covid19 using Topic Modeling,"International Conference on Smart Innovations in Design, Environment, Management, Planning and Computing (ICSIDEMPC), Aurangabad, India, 2020, pp. 279-282.

28. Tianyi Wang, Ke Lu, Kam Pui Chow, Qing Zhu, "COVID-19 Sensing: Negative Sentiment Analysis on Social Media in China via BERT Model,'Digital Object Identifier 10.1109/ACCESS.2020.3012595 3 vol 8, 2020, Pp. 138162- 138169, August 2020.

29. R. Wang, G. Hu, C. Jiang, H. Lu and Y. Zhang, "Data Analytics for the COVID-19 Epidemic," IEEE 44th Annual Computers, Software, and Applications Conference (COMPSAC), Madrid, Spain, 2020, pp. 12611266

\section{AUTHOR PROFILE}

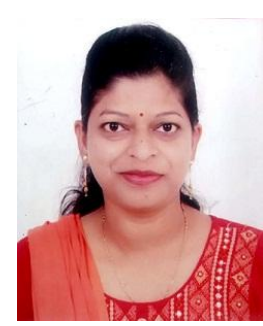

Dr. Binita Verma, is Assistant Professor in the Department of Science and Technology at Jayot Vidyapeeth Women's University, Jaipur, India. She is a Teacher, Researcher and Consultant in the field of Computer Science and Information Technology. She is a member of various professional Societies. She has published more than 10 research papers in reputed international journals including Thomson Reuters \& Scopus, Web of Science (SCI \& ESCI), and presented/participated in more than 35 national and international Conferences/Seminars/Webinars. Her research area are Data Mining, Machine Learning, Data Analytics and Artificial Intelligence. She has 10 years of teaching experience and 6 years of research experience.

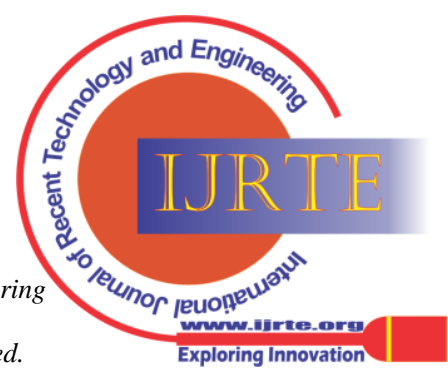

